\title{
HUBUNGAN PENGETAHUAN REMAJA PUTRI TENTANG ANEMIA DENGAN KEJADIAN ANEMIA DI KABUPATEN TANGGAMUS
}

\author{
Safira Laksmita*, Helmi Yenie* \\ *Jurusan Kebidanan Poltekkes Tanjungkarang
}

\begin{abstract}
Anemia merupakan salah satu masalah kesehatan di seluruh dunia terutama negara berkembang. Anemia banyak terjadi pada masyarakat terutama pada remaja putri. Hasil pra survey pada 40 remaja putri kelas XI di SMA Negeri 1 Talang Padang di dapatkan $70 \%$ mengalami anemia. Penelitian ini bertujuan untuk mengetahui Hubungan Pengetahuan Remaja Putri Tentang Anemia Dengan Kejadian Anemia Di Kabupaten Tanggamus. Desain penelitian yang digunakan adalah kuantitatif dengan pendekatan cross sectional. Pengambilan data diperoleh dengan cara pembagian angket dan pemeriksaan kadar $\mathrm{Hb}$. Populasi dalam penelitian ini adalah seluruh remaja putri kelas IX di SMA Negeri 1 Talang Padang yang berjumlah 231 responden. Sampel diperoleh dengan teknik sistematik random sampling dan diperoleh jumlah sampel sebanyak 145 responden. Analisa data menggunakan analisa univariat dan bivariat. Analisa univariat menggunakan persentase, sedangkan analisa bivariat menggunakan uji chi square. Hasil penelitian diperoleh $53,1 \%$ remaja putri memiliki pengetahuan kurang dan 46,9\% memiliki pengetahuan cukup. Pada kejadian anemia diperoleh, 62,8\% remaja putri mengalami anemia, dan 37,2\% tidak mengalami anemia. Kesimpulan diperoleh adanya hubungan antara Pengetahuan Remaja Putri Tentang Anemia Dengan Kejadian Anemia ( $p$-value 0,034, OR 2,22). Saran untuk tempat penelitian diharapkan adanya upaya penurunan angka kejadian anemia dengan memberikan penyuluhan dan pemeriksaan kadar $\mathrm{Hb}$ pada remaja putri oleh petugas Puskesmas.
\end{abstract}

Kata kunci: pengetahuan, kejadian anemia, remaja

\section{LATAR BELAKANG}

Anemia merupakan salah satu masalah kesehatan di seluruh dunia terutama negara berkembang yang diperkirakan $30 \%$ penduduk dunia menderita anemia. Anemia banyak terjadi pada masyarakat terutama pada remaja putri. Anemia defisiensi besi rentan terjadi pada remaja putri karena meningkatnya kebutuhan zat besi selama masa pertumbuhan. Tubuh membutuhkan sejumlah besar nutrisi, termasuk zat besi, yang terutama digunakan oleh darah untuk mengangkut oksigen. Zat besi yang tidak mencukupi akan memicu anemia. Ditambah lagi, kehilangan darah pada masa menstruasi juga meningkatkan risiko anemia. Menurut WHO, pada tahun 2010 angka kejadian anemia pada remaja putri di Negara-negara berkembang sekitar $53,7 \%$ dari semua remaja putri, anemia sering menyerang remaja putri disebabkan karena keadaan stres, haid, atau terlambat makanan. Sedangkan pada tahun 2013, prevalensi anemia dunia berkisar $40-88 \%$ (WHO, 2010). Prevalensi anemia pada remaja putri di benua Afrika adalah $44,4 \%$, benua Asia 33,0\%, benua Eropa $15,2 \%$, benua Amerika Latin dan Caribbean (LAC) 23,5\%, Benua Amerika Utara 7,6\% dan Benua Oceania prevalensi anemia sebesar 20,2\% (WHO, 2010). Provinsi Lampung tercatat sebagai peringkat pertama diwilayah sumatera untuk jumlah penderita anemia. Menurut survey yang dilakukan mercy Corps dari sampel 641 siswi ternate $56,25 \%$ siswi menderita anemia defisiensi gizi, prevalensi anemia untuk Lampung lebih tinggi dari nasional yaitu 27\% (Lampung sehat, 2011).

Berdasarkan Hasil Riset Kesehatan Dasar Provinsi Lampung tahun 2010 Presentasi anemia pada remaja sebesar 25,9 \%. Berdasarkan Profil Kesehatan Provinsi Lampung tahun 2011 untuk cakupan pelayanan kesehatan remaja, Kabupaten Tanggamus menempati urutan ke delapan dengan presentasi $38,17 \%$. 
Sedangkan dari data Puskesmas Kecamatan Talang Padang, didapatkan sasaran untuk cakupan pencapaian pelayanan kesehatan remaja, dari jumlah sasaran 3899 remaja, hanya 3219 remaja yang mendapatkan cakupan pelayanan kesehatan. Masih terdapat 680 remaja yang belum mendapatkan pelayanan kesehatan.

\section{METODE}

Desain penelitian kuantitatif dengan menggunakan pendekatan cross sectional. Populasi dalam penelitian ini adalah seluruh remaja putri kelas XI di SMA Negeri 1 Talang Padang dengan jumlah 231 siswi, dengan jumlah sampel sebesar 145 responden yang ditentukan dengan teknik sistematik random sampling.

Instrumen yang digunakan dalam penelitian ini berupa instrumen test dan lembar observasi. Data pengetahuan dikumpulkan dengan test sedangkan data anemia dikumpulkan dengan observasi. Pengolahan data dan analisis data menggunakan analisa unviariat dan bivariat menggunakan Chi-Square. Analisa univariat bertujuan untuk menjelaskan atau mendeskripsikan karakteristik setiap variabel penelitian meliputi pengetahuan tentang anemia dan kejadian anemia. Analisa bivariat yang dilakukan terhadap dua variabel yang diduga berhubungan atau berkolerasi yaitu untuk mengetahui hubungan pengetahuan remaja putri tentang anemia dengan kejadian anemia.
HASIL

\section{Analisa Univariat}

Tabel 1: Distribusi Pengetahuan Remaja Putri Tentang Anemia

\begin{tabular}{|c|c|c|}
\hline Pengetahuan & $\mathrm{f}$ & $\%$ \\
\hline Cukup & 68 & 46,9 \\
\hline Kurang & 77 & 53,1 \\
\hline Jumlah & 145 & 100 \\
\hline
\end{tabular}

Berdasarkan tabel di atas dari 145 remaja putri dapat diketahui sebagian remaja putri memiliki pengetahuan tentang anemia yang kurang sebesar 53,1\%, sedangkan remaja putri memiliki pengetahuan tentang anemia yang cukup sebesar $46,9 \%$.

Tabel 2: Distribusi Kejadian Anemia pada Remaja Putri

\begin{tabular}{|c|c|c|}
\hline Kejadian Anemia & $\mathrm{f}$ & $\%$ \\
\hline Tidak Anemia & 54 & 37,2 \\
\hline Anemia & 91 & 62,8 \\
\hline Jumlah & 145 & 100 \\
\hline
\end{tabular}

Berdasarkan tabel di atas dari 145 remaja putri dapat diketahui sebagian besar remaja putri mengalami anemia dengan persentase $62,8 \%$, sedangkan remaja putri yang tidak mengalami anemia sebesar $37,2 \%$.

\section{Analisa Bivariat}

Tabel 5: Hubungan Pengetahuan Remaja Putri Tentang Anemia Dengan Kejadian Anemia

\begin{tabular}{|c|c|c|c|c|}
\hline \multirow[b]{2}{*}{ Pengetahuan } & \multicolumn{2}{|c|}{ Kejadian Anemia } & \multirow[b]{2}{*}{$p$ value } & \multirow[b]{2}{*}{ OR } \\
\hline & $\begin{array}{c}\text { Tidak } \\
\text { Anemia }\end{array}$ & Anemia & & \\
\hline Cukup & $\begin{array}{c}32 \\
(47,1 \%)\end{array}$ & $\begin{array}{c}36 \\
(52,9 \%)\end{array}$ & \multirow{3}{*}{0,034} & \multirow{3}{*}{2,222} \\
\hline Kurang & $\begin{array}{c}22 \\
(28,6 \%)\end{array}$ & $\begin{array}{c}55 \\
(71,4 \%)\end{array}$ & & \\
\hline Jumlah & $\begin{array}{c}54 \\
(37,2 \%) \\
\end{array}$ & $\begin{array}{c}91 \\
(62,8 \%) \\
\end{array}$ & & \\
\hline
\end{tabular}

Hasil analisis hubungan antara pengetahuan tentang anemia dengan kejadian anemia pada remaja putri 
diperoleh bahwa ada sebanyak 36 (52,9\%) remaja putri yang memiliki pengetahuan cukup tetapi mengalami anemia. Sedangkan diantara remaja putri yang memiliki pengetahuan kurang, ada 55 $(71,4 \%)$ remaja putri yang mengalami anemia. Hasil uji statistic chi-square antara pengetahuan anemia dengan kejadian anemia pada remaja putri diperoleh $p$-value $0,034(\alpha<0,05)$, artinya ada hubungan yang bermakna antara pengetahuan remaja putri tentang anemia dengan kejadian anemia.

\section{PEMBAHASAN}

\section{Pengetahuan Remaja Tentang Anemia}

Berdasarkan hasil penelitian, dari 145 responden didapatkan $68 \quad(46,9 \%)$ remaja putri memliki pengetahuan tentang anemia yang cukup, dan 77 (53,1\%) remaja putri memiliki pengetahuan tentang anemia yang kurang. Pengetahuan atau kognitif merupakan domain yang sangat penting dalam membentuk tindakan seseorang. Dari pengalaman dan penelitian terbukti bahwa perilaku yang didasari oleh pengetahuan lebih langgeng dari pada perilaku yang tidak didasari oleh pengetahuan (Notoatmodjo, 2010).

\section{Kejadian Anemia pada Remaja Putri}

Berdasarkan hasil penelitian, dari 145 responden didapatkan $62,8 \%$ remaja putri mengalami anemia, dan $37,2 \%$ remaja putri tidak anemia. Hasil ini menunjukkan bahwa sebagian besar remaja putri mengalami anemia. Tingginya angka kejadian anemia pada remaja putri dikarenakan pengetahuan tentang anemia masih kurang. Dampak anemia pada remaja putri diantaranya adalah Menurunkan kemampuan kerja, konsentrasi, dan kebugaran tubuh, Mengganggu pertumbuhan sehingga tinggi badan tidak mencapai optimal, Menurunkan kemampuan fisik, Pucat pada bagian wajah (Almatsier, 2010).

\section{Hubungan Pengetahuan Remaja Putri Tentang Anemia dengan Kejadian Anemia}

Berdasarkan hasil penelitian yang dilakukan di SMA Negeri 1 Talang Padang, memperlihatkan bahwa ada sebanyak $32(47,1 \%)$ remaja putri dengan pengetahuan tentang anemia "cukup" namun tidak anemia, sebanyak $22(28,6 \%)$ remaja putri dengan pengetahuan "kurang" tetapi tidak anemia, sebanyak $36(52,9 \%)$ remaja putri dengan pengetahuan tentang anemia "cukup" tetapi anemia, dan sebanyak $55(71,4 \%)$ remaja putri dengan pengetahuan "kurang" mengalami anemia. Hasil uji statistic chi-square antara pengetahuan anemia dengan kejadian anemia pada remaja putri kelas IX diperoleh $p$-value 0,034. Dengan demikian ada hubungan yang bermakna antara pengetahuan remaja putri kelas IX tentang anemia dengan kejadian anemia di SMA Negeri 1 Talang Padang tahun 2017. Dari hasil analisis diperoleh nilai Odds Ratio (OR) sebesar 2,222 artinya remaja putri yang memiliki pengetahuan tentang anemia yang kurang beresiko 2,22 kali mengalami anemia.

\section{KESIMPULAN}

Penelitian ini menyimpulkan bahwa sebagian besar remaja putri memiliki pengetahuan kurang $(53,1 \%)$ dan sebagian besar mengalami anemia (62,8\%). Selanjutnya berdasarkan analisis juga disimpulkan bahwa ada hubungan pengetahuan remaja putri tentang anemia dengan kejadian anemia.

Berdasarkan kesimpulan tersebut penulis menyarankan kepada pihak sekolah agar dapat meningkatkan pengetahuan remaja putri tentang anemia guna menurunkan angka kejadian anemia pada remaja putri khususnya di sekolah. Upaya itu dapat dilakukan dalam bentuk kerjasama antara pihak UKS sekolah dan Puskesmas. Selanjutnya bagi tenaga kesehatan diharapkan melakukan penyuluhan dan pemeriksaan kadar hemoglobin pada remaja putri. 
DAFTAR PUSTAKA

Almatsier, Sunita. 2010. Prinsip Dasar Ilmu Gizi. Jakarta: PT Gramedia Pustaka Utama.
Kemenkes RI, 2014, Laporan Riskesdas 2013. Jakarta: Kemenkes RI.

Notoatmodjo. 2010. Ilmu Perilaku Kesehatan. Jakarta: Rineka Cipta. 